\title{
PORTRAYING AL-QUR'AN IN CYBER MEDIA: PORTRAIT IN SOCIAL MEDIA FACEBOOK OF INDONESIAN MUSLIM
}

\author{
Nur Mahmudah \\ State Islamic Collage (STAIN) Kudus \\ mahmudahnung@gmail.com
}

\begin{abstract}
Finding the Qur'an in the online world illustrates the new ways of Muslims in interacting with the Qur'an. Social media as part of the virtual one has a function as a provider of religious information, as well as representation of the religious practices of society including the relations between Muslims and the Qur'an in Indonesia. Observing the relationship of Indonesian Muslim with the Qur'an in public space in cyberspace can be seen in their interaction on social networking. Portrait of the relationship of the Muslims with the Qur'an in the most popular social media, facebook becomes the purpose of this article. Using qualitative method, this article focuses research on facebook account of some users, who were selected by purposive sampling. The data was analyzed in a deductive manner. This study shows that there are at least two forms of relationships namely aesthetic and hermeneutical receptions. Aesthetic reception involves reading and memorizing the Qur'an. While hermeneutical one emerges in an attempt to interpret the Qur'an. These two forms of virtual receptions are in line with the forms of Muslim interaction with the Qur'an in the real world. However, this form of relationship is simple and functional.
\end{abstract}

Keywords: Living Qur'an, Social Media, Facebook, Virtual Reception

\section{Introduction}

Religion and media create a reciprocal relationship. Religion uses media as a tool of Islamic teaching and preaching. Media is an entity used to disseminate information including religious information. On the Internet era, the relationship between religion and the media becomes more complicated because internet do not merely accommodate religious messages and even the media in turn produced religious ways and brought new values in religion or provides a new theology (Kort, 2006, 363).

Social media is a derivative of new media (internet). Social media provides a variety of content that allows people in searching for religious information. For example, Cyber fatwa can be found easily. Rusli's research (Rusli, 2011: 6-10) which sees two sites, Islamic-Online and Fatwa-Online, shows that Cyberfatwa affirms the statement of all knowledge as a social construction. Both of them are influenced by the motives and interests of each. The Fatwa-Online directed by al-Lajnah al-Da'imah li al-Buhuts al-Ilmiyyah wa al-Ifta 'used the rigid and literal approach to the text. On the contrary, Islam-Online which was driven by Yusuf al-Qardhawi as a moderate man interprets the Shari'a in flexible and moderate ways.

Beyond its function as a provider of religious information, on the other hand, social media becomes a representation of the religious practices of society including the relations between Muslims and the Qur'an in Indonesia. We can see the relationship of Indonesian Muslim with the Qur'an in the public sphere by observing their interaction on social networking.

This article is to portray the Qur'an in the daily life of Muslim society in the era 
of cyber media. Talking about virtual Islam, it can be found in Garry L Bunt and Lampeter who map much about online Islam ranging in expression, the diversity of theological affiliations, political Islam on the internet in various countries, the vision of Sufism, authority to the future of online Islam. Garry L Bunt and Lampeter (Bunt and Lampeter, 2015: 28-44) discuss the translation of the Online Qur'an, recitation of the Qur'an in the form of audio and explanation of the Qur'an. This information is quite helpful in mapping the variety of content related to the online Qur'an, but Bunt and Lampeter have not provided an adequate description of online Islam related to the Qur'an and its Interpretation. Sahal (Sahal, 2016: 39 - 57) writes about the online Qur'an and its translation: MyQur'an al-Qur'an Indonesia, al-Qur'an Indonesia and AlQur'an Bahasa Indonesia. Sahal describes the reasons, experiences, and impacts of using digital Qur'an for students at two pesantren and students from a state university in Yogyakarta. Nafisatuzzahro (2016) wrote about the Qur'anic commentary on YouTobe. Her study concluded that the Qur'anic commentary on YouTobe created a new era of interpretation through audio-visual texts that solidify people's dependence on digital media. Thus, the discussion of the kind of Indonesian Muslim relation to alQur'an in facebook is expected to be fulfilled by this article.

\section{Method}

This research is qualitative research. The data collected from selected facebook accounts. Selected respondents were associated with the intensity of their interaction with Qur'an. This research is a model of living Qur'an study with cyberspace locus. Data from the selected respondents' facebook accounts were the primary data while the other data were secondary data. The data in this study were collected through documentation techniques. Then, they were reduced, displayed and analyzed by deductive analysis.

\section{Result and Discussion}

In the Global Web Index 2011 record, among Asian countries, Indonesia and Philippines get the first rank as the social media users at $78 \%$. The data compiled by Semicoast in 2012 put Indonesia as the fifth largest user of the world's largest social media users, twitter with 19.5 million users. While in the use of facebook, Indonesia was ranked as the 4th largest world (March 2016) with monthly active facebook users reaching the range of 82 million people (http://tekno.kompas.com/read/2016/04/15/10210007/Hampir.Semua.Pengguna.Internet.In donesia.Memakai.Facebook)

Afriani defines social media as an online medium that allows its users to participate easily. The form of participation is sharing information and creating content that will be delivered to other parties to comment and so on quickly and unlimitedly. Social media include blogs, social networks, wiki, forums and virtual worlds. The first three forms are the most common forms of social media (Afriani, 2011:24).

Social media is used extensively by users from various professions, and purposes including business, education and learning, political ideology, communication, entertainment, friendship, advertising or marketing (Mustafa and Hamzah, 2010: 50). According to Darmastuti, the use of social media in communication theory is believed to be able to change a person regarding beliefs, values, attitudes, worldviews, social organization, human nature, activity orientation and self-perception and others (Darmastuti, 2011: 225). Even according to Flew, social media allow its users to create virtual communities and virtual identities that are very different from those in the real world. (Flew, 2002: 11-25) Wulf reminded that the existing 
interactions and exposure in social media could make a person consciously or unconsciously adjusts to the information content that emerged including mirrored to form a world-view and self-perception (Piliang, 2004: 166-167). Several studies have suggested the influence of activity in social media that constitutes a variety of user behaviors. Thus, it is important to photograph those of the Indonesian Muslims in facebook as the most popular social media related to the Qur'an.

Facebook is the social media that is most widely used and favored by users in Indonesia as the global phenomenon of its popularity in the world. Facebook history (http://www.asal-usul.com/2009/03/facebook-data-dan-fakta-sejarah.html) started on February 4, 2006, by a Harvard University student, Mark Zuckerberg as an internal media for students on his campus. Facebook's name is taken from a term among US campuses to know each other among academic civitas. The next facebook users further expanded to some others around the world. Since September 11, 2006, Facebook has diversified its users by allowing all people who have valid email addresses with age restrictions so that these websites are no longer exclusive for students.

The users are free to create their profiles in which they can contain photos and other personal info. They can also send messages, join a group or more. Facebook sets up a user profile only accessible to users fellows who have been friends so that they can see each other's private profile content. Facebook has some features including the wall, space where users fellows send out messages either commenting or simply expressing support (giving like). In addition to sending messages, users can also send attachments of links, apps and the like directly to the wall. Besides, they also can send some attachments, applications and many others to the facebook wall. They can send friend requests to fellows to expand the network. There is also a search ${ }^{\text {ee }}$ feature to help users find friends by typing their facebook account of the person who are being searched. The next feature is "Poke", the means to tangle each other virtually. 'Photose feature is for posting a picture, and "status" shows the current users" condition. Some of these features confirm the position of facebook as a social networking site that allows users to share information, establish relationships with old and new friends and communicate. Another feature is "notee which was added starting August 22, 2006. In this feature, users can write long notes and or import their writing on other blogs to be displayed on Facebook. Another feature released in 2008 is "Chat" which allows the users to send personal messages directly and in real time.(http://www.asalusul.com/2009/03/facebook- data-dan-fakta-sejarah.html)

This article looks at the activities of the facebook users about the widely accessible Qur'an that is on the features of the wall, the status and the records of its users. The receptions will be photographed in two forms. First, the aesthetic one which is the process of acceptance with the eyes and ears, the art experience and the taste of the reader. In short, it is related to psychological appreciation and acceptance. Another one is hermeneutical receptions. It covers the achievements of the study of textual interpretation and the interpretation activity of the text itself (Setiawan, 2008: 6892).

The aesthetic reception of the Qur'an is seen in the recitation of the Qur'an. One facebook account that describes recitation activities of the Qur'an is the facebook of the ODOJ community, One Day One Juz and or Kampung Qur'an. ODOJ which obliges its members to complete a certain number of Qur'anic recitations uses facebook media and some other social media in campaigning, affirming and monitoring the quota of its members. (www.odojersregionalkudusfb.com)

The second reception which is the hermeneutical reception of the Qur'an found in many facebook users interactions, for example, facebook account of Muhammad 
Quraish Shihab (web.facebook.com/mqshihab). He often makes a post about the study of the Qur'an in the form of the disclosure of the essence or conclusion. In a status on March 22, 2016, at 11:07, Quraish wrote the word Ihsan. He said that the word Ihsan is wider than giving a favor or a living and beyond the content of meaning in the word 'adl. Ihsan concluded treating the other side better than the treatment he received. This fragment is part of the contents of Quraish Shihab's other books, the collection of 101 Kultum on Islam. In another status on December 28, 2015, that only Allah knows the faith of a person, he calls Q. al-Mumtahanah: 10 "Allah knows their faith." This status is quoted from his book al-Lubab: The Meaning, Purpose, and Lesson of the Surahs of the Qur'an. While in a status on March 25, 2016, Quraish Shihab shared by giving the Alif magazine "Magazine" link when writing the different names of Allah al-Wadud with al-Rahman. This discussion has been published in Alif Magazine on April 15, 2013, stemming from Muhammad Arifin's answer, the expert board of the Qur'an Study Center (http://alifmagz.com/qurean-answer/apa-perbedaan-antara-nama-allah-alwadud- dengan-ar-rahman/ ). He often shares some videos on his account. As the example, Quraisy uploaded the video on June 15, 2016, when he discussed what an alQur'an said about heaven and judgment day. (https://web.facebook.com/pg/mqshihab/posts/?ref=page_internal)

Facebook account of Salman Harun, professor of tafsir at UIN Syarif Hidayatullah regularly contains interpretations of the surah in juz 'amma. This interpretation is later referred to as facebook tafsir. It began on October 5, 2015, when he shared it in his post. Later it can also be seen in Salman Harun's personal website on www.salmanharun.com since 20 August 2016. The number of verses interpreted in a single post varies from one to five. His interpretive model is to write a translation followed by a brief and concise explanation without mentioning the referenced source (http//Salman Harunfacebook.com). As the example is his posting on March 4, 2016, about Q. Al-Syarh: 1. There, he said: The task of educating humankind to believe and do good things often suffocates because of the confrontation of some people. Allah gives patience to the Prophet Muhammad to face the opposition by giving him the perfect guidance (guidance gives the patience and the perplexity makes hurts, like go up on the sky, see Q. 6: 125).

In the comments above, Salman attempts to bring the meaning of the sentence compactly and concisely. Source incontinence is possible due to the brief nature of the reviews as we can find in ijmali interpretation model.

In contrast to Salman, Ahmad Thib Raya's facebook account which in fact is a professor of Arabic language in UIN Syarif Hidayatullah attempts to give an explanation of the Qur'an or Qur'anic commentary specifically in the language perspective. This account specifically and continuously provides Arabic lessons via facebook. The language of the Qur'an which is in Arabic gives space in this account to discuss Qur'anic verses like in the account of August 14, 2016 when he describes the word form in Q. al-Syu'ara' (25 ): 80 "wa iza maridtu fahuwa yasyfin" and the previous two verses shaped mufrad and ended by nun wiqayah and ya' al-mutakalim. Thus this verse originally sounds yasyfini, then $y a^{\prime}$ is discarded to harmonize the end of the verse (www Ahmadthibraya- facebook.com).

This hermeneutical reception is generally found in the status of the account owner. The pattern of it is usually done by people who have a sufficiently qualified religious understanding of the Qur'an so they use space in facebook to give an explanation of the Qur'an. Within the space limitations, the writers or users often do not mention the sources of interpretation.

Another form of hermeneutical phenomenon is quoting verses and 
translations or verses in the status of a person and / or community, for example facebook of kampung al-Qur'an Ponorogo that made the page began from September 23, 2016. Kampung al-Qur'an Ponorogo is an institution that opens the service learning to read al-Qur'an from zero and tahsin for adults who are over 20 years old. They sometimes quote verses of the Qur'an on their walls which are mostly verses and translations. Like the status uploaded on November 25, 2016, it contains verses and translations of Q. al-Nisa ': 36 (www.kampung al Qur'an Ponorogofb.com.).

The findings of this study show two forms of aesthetical and hermeneutical receptions as virtual receptions of Muslims against the Qur'an in line with the form of Muslim reception of the Qur'an in the real world. Islah (2004) mentions in the struggle of the Indonesian Muslims with the Qur'an, there is a variety of expression, starting aesthetic, mythic to hermeneutical. Study of Mahmudah (2016) which specifically looked at the pesantren community in East Pantura provided information on the existence of four types of liturgical, ethical, intellectual and magical receptions. It shows that the form of interaction of Muslims in the real world and the virtual world have similarities. This finding supports the view that virtual reality in the cyber universe is a reflection of the real one in everyday life that is transferred to the virtual world including religious activities (Muttaqin, 2016).

In some ways, by the nature of the online media, the religious activity of the relationship of the Muslims with the Qur'an has some differences. The virtual reality that allows for virtual interaction among its users can be seen in selected respondent facebook accounts which accommodate the comments and questions directly from readers related to the post about the Qur'an, especially the hermeneutical one. Good comments provide positive support by giving likes (like) and other comments. Heim (1993: 110 - 116) calls this phenomenon as one of the properties of virtual reality, a form of direct interaction that allows its users to connect unlimitedly.

\section{Conclusion}

This article finds a portrait of Muslim interaction with the Qur'an in online media facebook at least in two forms of receptions, whether aesthetic or hermeneutical. Aesthetic receptions have the form of recitation of the Qur'an while hermeneutical receptions take the form of verses, translations and interpretations in facebook accounts of both individuals and organizations. The use of online media in this interaction designates the use of facebook in communication, education and learning. If it is related to the theory of communication about the potential of facebook in changing a person in terms of beliefs, values, attitudes, worldviews, social organization, human nature, activity orientation as well as self-perception and others, then raises the need to unveil categorization and implication of facebook study on another occasion. Wallahu yahdi ila sawa'al-sabil.

\section{References}

Bunt, Garry R and Lampeter. 2005. Islam Virtual: Menjelajah Islam di Jagad Maya translated by Suharsono, Yogyakarta: Suluh Press.

Flew, Terry. 2002. New Media: an Introduction. New York: Oxford University Press.

Heim, Michael. 1993. The Metaphysics of Virtual Reality. New York: Oxford Universty Press.

Gusmian, Islah. 2004. "Al-Qur"an dalam Pergumulan Muslim Indonesia”. In Jurnal Taswirul Afkar 18th edition.

Kaelan. 2015. Metode Penelitian Kualitatif bidang Filsafat.Yogyakarta: Paradigma

Kort, Alexis. 2005. "Dar al-Cyber Islam: Women, domestic violence, and the Islamic 
reformation on the World Wide Web" dalam Journal of Muslim Minority Affairs. Vol. 25 Issue 3

Mahmudah, Nur. 2016. Biografi al-Qurean dalam Masyarakat Pesantren di Pantura Timur. Prosiding Seminar Internasional al-Qur'an. Jakarta: Lembaga Pentashihan Mushaf al-Qur"an.

Muttaqin. Husnul. "Merangkai Keimanan di Dunia Cyber (Kajian Sosiologis Atas Konstruksi Model-Model Pemahaman Keagamaan di Halaman Komunitas Jaringan Islam Liberal di Situs Jejaring Sosial Facebook. Laporan Penelitian Dosen UIN Sunan Ampel Surabaya. Tersedia secara online dalam www.digilib.uinsby.ac.id Accessed on 27 August 2017

Nafisatuzzahro. 2016. "Tafsir al-Qur"an Audio Visual di Cyber Media: Kajian Terhadap Tafsir al-Qur"an di You To Be dan Implikasinya Terhadap Studi al-Qur"an" Tesis, UIN Sunan Kaljaga Yogyakarta.Yasfar Amir Piliang. (2004) Dunia Yang Dilipat. Yogyakarta: Jalasutra.

Rusli. 2014. "Progressive Salafism in Online Fatwa" dalam al-Jamiecah: Journal of Islamic Studies Vol. 52 No. 1. DOI:http://dx.doi.org/10.14421/ajis.2014.521.205-229

Sahal, Mohamad Sobirin. 2016. "Digital al-Qur"an and Its Translation: Understanding the "New" Mushaf and Indonesian Muslim"s Religious Experience in New Media World" in Proseding Seminar Internasional al- Qur'an Lajnah Pentashihan Mushaf al-Qur"an Kementrian Agama Republik Indonesia.

Setiawan, Nur Kholis. 2008. Al-Qur'an Kitab Sastra Terbesar. Yogyakarta: Elsaq Press.

Syamsuddin, Sahiron $\quad$ (ed.). 2007. Metodologi Penelitian Living Qur'an dan Hadis. Yogyakarta: TH-Press and Teras.

Utari, Prahastiwi. 2011. "Media Sosial, New Media dan Gender dalam Pusaran Teori Komunikasi” dalam Komunikasi 2.0: Teoritisasi dan Implikasi. Yogyakarta: Aspikom.

www.kampung al Qur'an Ponorogofacebook.com.

www.facebook.com/mqshihab

http//Salman Harunfacebook.com.

www. Ahmadthibraya-facebook.com

www.odojersregionalkudusfb.com 